\title{
THE POSSIBILITY OF DAIRY FARMS ISOLATION ASSESSMENT - BIOSECURITY ASPECT
}

\author{
B. Stanković ${ }^{1}$, S. Hristov ${ }^{1}$, J. Bojkovski ${ }^{2}$, Z. Zlatanović ${ }^{3}$, N. \\ Maksimović $^{4}$, M. Todorović-Joksimović ${ }^{1}$, V. Davidović ${ }^{1}$
}

${ }^{1}$ University of Belgrade, Faculty of Agriculture, Nemanjina 6, 11080, Belgrade-Zemun, Republic of Serbia

${ }^{2}$ University of Belgrade, Faculty of Veterinary Medicine, Bulevar oslobođenja 18, 11000, Belgrade, Republic of Serbia

${ }^{3}$ High Agriculture and Food Processing School of Professional Studies, Ćirila i Metodija 1, 18400 Prokuplje

${ }^{4}$ Institute for Animal Husbandry, Autoput 16, P. Box 23, 11080, Belgrade-Zemun, Republic of Serbia Corresponding author: baxton@agrif.bg.ac.rs

Original scientific paper

Abstract: The effects of general and special biosecurity measures to prevent introduction of infectious agents in a dairy farm or its spreading from farm were analysed in details in this paper. Investigations were conducted on five different dairy farm production with different technology and capacity using a questionnaire method (Hristov and Stanković, 2009), as well as scrutinizing their positions in relation to possible sources bio-risks from the near and far away environment. Test results showed that there are serious shortcomings on all observed farms, regarding the possibility of introduction of infectious agents in the production herd, and its possible spread to the environment. Although all fenced and a position of the most of the farms mostly favourable, there are some serious threats to the herd health and farm production, regarding open space and lack of green belt, the uncontrolled presence of wild birds and rodents in facilities and even in feed storage, as well as contact of the employees with other cows not belonging to the farm.

Key words: biosecurity, isolation, dairy, farm

\section{Introduction}

Since the early 1900 s, it could be found in veterinary texts that there are a cause and effect relationship between animal contact and disease (Anderson, 1998) and that livestock producers recognized animal movements as important routes for the disease dissemination (Woolhouse and Donaldson, 2001). No matter of level of reference (individual, herd or farm level), infectious diseases transmission is related to any form of contact, direct or indirect (Brennan et al., 2008). 
There are a number of diseases (bovine tuberculosis, foot and mouth disease FMD, e.g.) are being spread by movement of animals (Gibbens et al., 2001; Gilbert et al., 2005; Woolhouse et al., 2005) which was clearly confirmed during the 2001 FMD outbreak in the UK (Ortiz-Pelaez et al., 2006). There is no doubt that all other kind of contacts may also lead to transmission of infectious agents: equipment sharing, movement of people - contractors or visitors, movement of vehicles, contact over/through fences with neighbouring stock, etc. It has been reported that wildlife and even wind can play a role in transmission between contiguous or nearby production units (Mikkelsen et al., 2003; Woodroffe et al., 2006). Therefore, the effects of general and special biosecurity measures to prevent introduction of infectious agents in a dairy farm or its spreading from five observed farm were analysed in details in this paper.

\section{Materials and Methods}

Investigations of the effects of general and special biosecurity measures undertaken by stakeholders in order to prevent introduction of infectious agents in a dairy farm or its spreading from farm were conducted on five different dairy farms with different technology and capacity (farm A: 420 cows in loose system of rearing; farm B: 100 cows in loose system of rearing; farm C: 350 cows in loose system of rearing; farm D: 20 cows in tied system of rearing and farm E: 12 cows in tied system of rearing), as well as scrutinizing their positions in relation to possible sources of bio-risks from the near and far away environment.

Biosecurity indicators related to isolation of the farm (position and isolation level, introduction of newly acquired animals into the herd, traffic control, attitude towards visitors, feeding and watering control, manure management, attitude towards other animals, rodents and birds' control, sanitation) were considered and evaluated.

In order to evaluate relevant biosecurity indicators, grades were defined: 5 excellent, 4 - very good, 3 - good, 2 - sufficient, 1 - insufficient, there are resources for improvement 0 - insufficient, with no resources for improvement, and rating scale: 0-1,99 insufficient, 2,00-2,49 sufficient, 2,5-3,49 good, 3,5-4,49 very good and 4,5-5,00 excellent, were defined.

SWOT analysis (Strength, Weakness, Opportunity and Treat) was performed afterwards, completing data of possibilities of dairy farms isolation as biosecurity aspect of production.

\section{Results and Discussion}

In Table 1 are given results of biosecurity indicators evaluation of five farms in respect of estimated isolation level. At two of five observed farms isolation level 
was evaluated as insufficient (farms D and E, 1.74 and 1.26, respectively), at two it was good (farms B and C, 3.27 and 3.39, respectively), and only on one it was very good (farm A, 3.63).

Table 1. Results of evaluation of 5 farms in respect of possibilities of their isolation

\begin{tabular}{||l|c|c|c|c|c||}
\hline \hline \multirow{2}{*}{ INDICATOR } & \multicolumn{5}{|c||}{ FARM } \\
\cline { 2 - 6 } & $\mathrm{A}$ & $\mathrm{B}$ & $\mathrm{C}$ & $\mathrm{D}$ & $\mathrm{E}$ \\
\hline $\begin{array}{l}\text { Size of farm (number of } \\
\text { cows) }\end{array}$ & 420 & 100 & 350 & 20 & 12 \\
\hline System of rearing isolation & 3.80 & 4.22 & 3.80 & 1.20 & 0.60 \\
\hline $\begin{array}{l}\text { 1. Position and } \\
\text { level }\end{array}$ & 4.29 & 4.21 & 5.00 & 1.29 & 1.25 \\
\hline $\begin{array}{l}\text { 2. Introduction of newly } \\
\text { acquired animals into the } \\
\text { herd }\end{array}$ & 2.30 & 1.74 & 1.20 & 0.70 & 0.80 \\
\hline $\begin{array}{l}\text { 3. Traffic control loose } \\
\text { 4. Attitude towards visitors }\end{array}$ & 1.67 & 2.13 & 2.14 & 1.43 & 1.43 \\
\hline $\begin{array}{l}\text { 5. Feeding and watering } \\
\text { control }\end{array}$ & 3.00 & 4.00 & 3.00 & 2.43 & 2.57 \\
\hline 6. Manure management & 3.00 & 4.00 & 5.00 & 4.00 & 1.33 \\
\hline $\begin{array}{l}\text { 7. Attitude towards other } \\
\text { animals, rodents and birds } \\
\text { control }\end{array}$ & 2.58 & 2.43 & 1.67 & 1.40 & 0.89 \\
\hline 8. Sanitation & 3.86 & 3.47 & 2.50 & 1.50 & 1.21 \\
\hline Average rate of the farm & 3.63 & 3.27 & 3.39 & 1.74 & 1.26 \\
\hline Total rate of all 5 farms & & 2.60 & & \\
\hline
\end{tabular}

Generally, farms D and E, located inside of human settlements, were rated as insufficient (1.20 and 0.60 , respectively), as well as introduction of newly acquired animals into the herd (1.29 and 1.25). These farms are rather small and eventual loses caused by disease would be tolerable.

As the greatest weakness was recognized the traffic control, because it was rated as insufficient at four of five farms (farms B, C, D and E: 1.74, 1.20, 0.70 and 0.80 , respectively), attitude towards visitors on three farms (farms A, D and E: $1.67,1.43$ and 1.43 , respectively) as well as the attitude towards other animals, rodents and birds control on farms: C, D and E (1.67, 1.40 and 0.89 , respectively). Sanitation was rated as very good only at one farm (farm A, 3.86) and good at farms B and C (3.27 and 3.39), but insufficient at farms D and E (1.74 and 1.26).

Although the average grade for all observed farms was good (2.60), general attitude of farms owners towards necessity to isolate their production unit is generally problematic, partly because dairy production is mainly outdoor oriented, so they conclude that contact with other farms, people and other species are inevitable. Studies conducted in The Netherlands, California and New Zealand have identified and quantified these contacts over time, particularly with regard to 
the potential spread of FMD (Brennan et al., 2008). The number of contacts varies greatly when considering characteristics such as type of enterprise, size of farm and number of animals on farm (Bates et al., 2001; Nielen et al., 1996; Sanson et al., 1993), illustrating the structural complexity and heterogeneity of the contacts that exist between farms. Cattle, particularly calves, tended to be transported individually. Social visits are responsible for a large number of contacts, and in $25 \%$ of these visits the persons had contact with the farm animals, causing the contact to be a high risk for spread of FMD. Cattle farms and mixed pig and cattle farms have more contacts than pig farms, respectively, but the contact pattern would be expected to change drastically after the declaration of an outbreak of foot-and-mouth disease, because of the movement restrictions that would be imposed (Nielen et al., 1996). Measure of importance of these facts was presented in paper by van Schaik et al. (1998). In this paper, Bovine Herpes Virus 1 (BHV1)positive farms were found to be situated closer to other cattle farms and had more (professional) visitors in the barn that used farm clothing less often and purchased cattle and participated in cattle shows more often, compared with the BHV1negative farms.

In addition, all ways of transport are expanding in reach, speed of travel and volume of passengers and goods carried, so pathogens and their vectors can now move further, faster and in greater numbers than ever before. Three important consequences of global transport network expansion are infectious disease pandemics, vector invasion events and vector-borne pathogen importation (Tatem et al., 2006). This means that the role of the visitors from other countries as potential pathogen carriers increases and must not be neglected.

Nevertheless, there is permanent problem on dairy or beef cattle farms is misunderstanding or even deliberate neglect of the importance of systematic application of biosecurity measures by employees and/or owners, in respect of isolating and layout of individual buildings, the introduction of newly acquired animals in the herd, footbaths functioning, as well as the technological way of doing repetitive tasks such as feeding or milking, use of medical materials and disposal of carcasses. Procedures for sanitation facilities, resources and animals are often not respected, as well as managing data related to the envisaged and applied biosecurity measures (Stanković et al., 2010a; Stanković et al., 2010b; Stanković et al., 2011).

Obtained data revealed that feeding and watering could be rated as good on all observed farms, but problem of mixed use of equipment and vehicles for both feedstuffs and waste managing and transport might introduce pathogens into herd anytime, especially for younger categories.

Manure management is rather good organized on all farms. According to Oliver et al. (2005), good manure management practices are critical in assuring dairy farm hygiene. Identification of on-farm pathogen reservoirs could aid with 
implementation of farm-specific pathogen reduction programs. Manure, lagoon water and bedding constituted areas have to be of major concern on dairy farms.

\section{Conclusion}

According to obtained and analysed data regarding possibility of commercial farms isolation as aspect of biosecurity it could be concluded:

- although all fenced and a position of the most of the farms mostly favourable, there are some serious threats to the herd health and farm production, regarding open space and lack of green belt, the uncontrolled presence of visitors, birds and rodents in facilities and feed storage areas;

- general attitude of farms owners towards necessity to isolate their production unit is usually problematic, partly because dairy production is mainly outdoor oriented, so they conclude that contact with other farms, people and other species are inevitable;

- visitors policy and traffic control, as well as sanitation procedures both at the gate and on the farm are the key of good herd health status and successful production.

\section{Acknowledgment}

The paper was financed by Ministry of Education and Science, Republic of Serbia, project TR31086.

\section{Procena mogućnosti izolacije farmi muznih krava - biosigurnosni aspekt}

B. Stanković, S. Hristov, J. Bojkovski, Z. Zlatanović, N. Maksimović, M. TodorovićJoksimović, V. Davidović

\section{Rezime}

U radu su detaljno analizirani efekti preduzetih opštih i posebnih mera biosigurnosti koji se odnose na sprečavanje unošenja infektivnog materijala u farmu muznih krava ili njegovog širenja sa farme. Ispitivanja su obavljena na 5 farmi muznih krava različite tehnologije proizvodnje i kapaciteta metodom upitnika (Hristov i Stanković, 2009), kao i sagledavanjem položaja farme u odnosu na moguće izvore biorizika u bližoj i daljoj okolini. Rezultati ispitivanja ukazuju da na svim posmatranim farmama postoje ozbiljni nedostaci u pogledu mogućnosti 
unošenja infektivnih agenasa u proizvodni zapat, ali i njegovog mogućeg širenja na okolinu.

Iako su sve ograđene, a položaj većine ispitivanih farmi uglavnom povoljan, otvorenost prostora i nedostatak zelenog pojasa, nekontrolisano prisustvo divljih ptica i glodara u objektima za držanje krava pa čak i smeštaj hrane, kao i kontakt zaposlenih sa drugim govedima koja ne pripadaju farmi predstavljaju ozbiljnu pretnju po zdravstveno stanje zapata i proizvodnju farme.

\section{References}

ANDERSON J. F. (1998): Biosecurity - a new term for an old concept - how to apply it. Bov. Pract., 32, 61-70.

BATES T.W., THURMOND M.C., CARPENTER T.E. (2001): Direct and indirect contact rates among beef, dairy, goat, sheep, and swine herds in three California counties, with reference to control of potential foot-and-mouth disease transmission. Am. J. Vet. Res., 62, 1121-1129.

BRENNAN M.L., KEMP R., CHRISTLEY R.M. (2008): Direct and indirect contacts between cattle farms in north-west England. Preventive Veterinary Medicine, 84, 242-260.

GIBBENS J.C., SHARPE C.E., WILESMITH J.W., MANSLEY L.M., MICHALOPOULOU E., RYAN J.B.M., HUDSON M. (2001): Descriptive epidemiology of the 2001 foot-and-mouth disease epidemic in Great Britain: the first five months. Vet. Rec., 149, 729-743.

GILBERT M., MITCHELL A., BOURN D., MAWDSLEY J., CLITON-HADLEY R., WINT W. (2005): Cattle movements and bovine tuberculosis in Great Britain. Nature, 435, 491-496.

HRISTOV S., STANKOVIĆ B. (2009): Welfare and biosecurity indicators evaluation in dairy production. 2009. Biotechnology in Animal Husbandry, 25, 5-6, 623-630.

MIKKELSEN T., ALEXANDERSEN S., ASTRUP P., CHAMPION H.J., DONALDSON A.I., DUNKERLEY F.N., GLOSTER J., SORENSEN J.H., THYKIER-NIELSEN S. (2003): Investigation of airborne foot-and-mouth disease virus transmission during low-wind conditions in the early phase of the UK 2001 epidemic. Atmos. Chem. Phys., 3, 2101-2110.

NIELEN M., JALVINGH A.W., HORST H.S., DIJKHUIZEN A.A., MAURICE H., SCHUT B.H., VAN WUIJCKHUISE L.A., DE JONG M.F. (1996): Quantification of contacts between Dutch farms to assess the potential risk of footand-mouth disease spread. Prev. Vet. Med., 28, 143-158.

OLIVER S.P., MURINDA S.E., NGUYEN L.T., NAM H.M., ALMEIDA R.A., HEADRICK S.J. (2005): On-farm sources of foodborne pathogens: isolation from the dairy farm environment. 4th IDF International Mastitis Conference, Maastricht, 
The Netherlands, 12-15 June 2005, 665-670; http://v2.mlc.org.uk/downloads/ pdfs / Appendix1.pdf

ORTIZ-PELAEZ A., PFEIFFER D.U., SOARES-MAGALHAES R.J., GUITIAN F.J. (2006): Use of social network analysis to characterize the pattern of animal movements in the initial phases of the 2001 foot and mouth disease (FMD) epidemic in the UK. Prev. Vet. Med., 76, 40-55.

SANSON R.L., STRUTHERS G., KING P., WESTON J.F., MORRIS R.S. (1993): The potential extent of transmission of foot-and-mouth-disease - a study of the movement of animals and materials in Southland, New-Zealand. N.Z. Vet. J., 41, 21-28.

STANKOVIĆ B., HRISTOV S., PETRUJKIĆ T., BOJKOVSKI J., MAKSIMOVIĆ N., DELIĆ N. (2011): Analysis of applied biosecurity measures in boars sperm production. Biotechnology in Animal Husbandry, 27, 2, 209-216.

STANKOVIĆ B., HRISTOV S., ZLATANOVIĆ Z. (2010a): Planovi biosigurnosti na farmama goveda i svinja. Zbornik naučnih radova Instituta PKB Agroekonomik, $16,3-4,125-132$.

STANKOVIĆ B., HRISTOV S., BOJKOVSKI J., MAKSIMOVIĆ N. (2010b): Health status and bio-security plans on pig farms. Biotechnology in Animal Husbandry, 26, 1-2, 29-35.

TATEM A. J., ROGERS D. J., HAY S. I. (2006): Global transport networks and infectious disease spread. Adv Parasitol., 62, 293-343.

VAN SCHAIK G., DIJKHUIZEN A.A., HUIRNE R.B., SCHUKKEN Y.H., NIELEN M., HAGE H.J. (1998): Risk factors for existence of Bovine Herpes Virus 1 antibodies on nonvaccinating Dutch dairy farms. Prev Vet Med., Feb 27, 34, 2-3, 125-36.

WOODROFFE R., DONNELLY C.A., JENKINS H.E., JOHNSTON W.T., COX D.R., BOURNE F.J., CHEESEMAN C.L., DELAHAY R.J., CLIFTON-HADLEY R.S., GETTINBY G., GILKS P., HEWINSON R.G., MCINERNEY J.P., MORRISON W.I. (2006): Culling and cattle controls influence tuberculosis risk for badgers. Proc. Natl. Acad. Sci. U.S.A., 103, 14713-14717.

WOOLHOUSE M., DONALDSON A. (2001): Managing foot-and-mouth-the science of controlling disease outbreaks. Nature, 410, 515-516.

WOOLHOUSE M.E. J., SHAW D.J., MATTHEWS L., LIU W.C., MELLOR D. J., THOMAS M.R. (2005): Epidemiological implications of the contact network structure for cattle farms and the 20-80 rule. Biol. Lett. UK 1, 350-352. 